\title{
CAN RELATIONSHIP BENEFITS MAKE CUSTOMERS COMMITTED AND LOYAL?
}

\author{
Fransisca Andreani ${ }^{*}$, Laurencia Jap ${ }^{2}$, Ivana Karina Hosea ${ }^{3}$ \\ ${ }^{1,2,3}$ Hotel Management Program, Petra Christian University, \\ Jl. Siwalankerto 121-131, Surabaya 60236, Indonesia \\ *Coressponding author; Email: ${ }^{1}$ andrea@ petra.ac.id
}

\begin{abstract}
Tough competition has pushed four-star hotels in Surabaya to manage their competitive strategies. One of them is by providing relationship benefits to maintain customer commitment and loyalty. Customers experiencing relational benefits may become committed. It can lead them to become loyal to the hotel. This study is to reveal the impact of relationship benefits (confidence, social and special treatment benefits) on customer commitment and the impact of customer commitment on customer loyalty in four-star hotels in Surabaya. Partial Least Square (PLS) is used to analyze data. The results show that relationship benefits have positive and significant impacts on customer commitment; and customer commitment also has positive and significant impact on customer loyalty.
\end{abstract}

Keywords: Relationship benefits, customer commitment, customer loyalty.

\section{Introduction}

In recent years, hotel industry has grown very significantly due to the rapid growth of tourism industry. Central Bureau of Statistics noted the number of foreign tourist arrivals to Indonesia has increased since 2006. A total of 9.7 million foreign tourists have visited Indonesia in 2015, growing by $3.11 \%$ compared to 2014. The high number of tourists makes Indonesia ranked the third in Asia in the field of hospitality development after China and India (Industri Perhotelan dan Tren Pariwisata di Indonesia, 2014). This is also due to the growing number of middleclass society who has more buying power, as well as air connectivity with competitive low cost carrier models that allow people to travel easily.

Along with the hotel growth in Indonesia, especially in Surabaya, competition in the hotel business is getting tighter and tighter. To be superior, hotels certainly need appropriate strategies to get more customers to choose the hotels as their accommodation (Triangga \& Kurniawan, 2004). To some extent, hotel strategies need to be adjusted accordingly. Hotels that were once more focused on transactional activities must now begin to pay more attention to their activities in order to get closer relationship and know more about their customers' needs and to provide more benefits to the customers (Hennig-Thurau, Gwinner, \& Grembler, 2002).

In the hospitality industry, building good relationships with customers is an important competitive strategy. This is considered more powerful than the value added a hotel can afford (Zineldin, 2006).
However, customer relationships do not arise on their own, but rather through the hotel's benefits offered to its customers that will evolve over time and experience (Cooil, Keiningham, Aksoy, \& Hsu, 2007). Relationship benefits include confidence benefits, social benefits, and special treatment benefits (HennigThurau et al., 2002). Along with the customer experience in enjoying the provided benefits, then the relationship with customers will also develop. This will lead to the emergence of relationship quality which then impacts on customer loyalty.

Based on a research by Dagger and O'Brien (2010), after the hotel gives all the advantages to the customers, then the relationship quality will be formed. Relationship quality consists of three variables, namely satisfaction, trust, and commitment that affect customer loyalty. In this study, the authors want to focus the research on the influence of relationship benefits to one variable of relationship quality that is commitment. Commitment is the willingness of customers to continue to maintain good relationships established by the hotel (Caceres \& Paparoidamis, 2007). Commitment will encourage customer loyalty. Loyal customers who spread positive words of mouth, make recommendations, and loyal to the products or services offered by the hotel in the future. Furthermore, this is also because there are hardly a few researches that specifically discuss the antecedent that encourages the formation of customer commitment (Dagger, David, \& Ng, 2011).

From the literature reviews, it is found that each hotel has its own way of providing relationship benefits to its customers. Starting from a five-star hotel to a 
non-star hotel, both hotels really care more about the added value of relationship benefits than the main services offered by them to their customers (HennigThurau et al., 2002). So, in this study the authors choose four-star hotels as the objects of the study because four-star hotels are growing rapidly in the hospitality industry, especially in Surabaya as the main hub of commercial activities. There are four more four-star hotel projects (Mercure @Praxis, Swiss-Belhotel Darmo Surabaya, Harris HR Mohammad, Four Points by Sheraton Surabaya, Pakuwon Indah) in 2017-2018 in Surabaya (Yonasari, 2019). It's also because there is a high level of contact between customers and service providers in four and five-star hotels (McColl-Kennedy \& White, 1997). In addition, the authors find no similar research that discusses the relationship between the three variables, especially the impact of relationship benefits on customer commitment and the impact of customer commitment on customer loyalty in four-star hotels in Surabaya. Therefore, this study will explore the relationship benefits the four-star hotels offer to their customers in Surabaya and the extent to which the benefits affect customer commitment and loyalty. Hopefully, the results of this study will be useful for hotel managers to establish necessary strategies to maintain customer commitment and loyalty

\section{Relationship Benefits}

To maintain a good relation in business, a relationship must be mutually beneficial. The relationship benefits approach is used to understand customer motivation to maintain long-term relationships with hotels (Kinard \& Capella, 2006). Relationship benefits received by customers must be able to add value to customer experience while using hotel services (Zineldin, 2006). Gwinner, Gremler, and Bitner (1998) state that customers who are in long-term relationships feel three basic types of relationship benefits, namely:

1. Confidence benefits

2. Social benefits

3. Special treatment benefits

Confidence benefits refer to the perception of less anxiety in transacting and increasing realistic expectations of the hotel (Yen \& Gwinner, 2003). These also refer to the feelings of confidence and trust in the hotel (Wong, Deans, \& Todd, 2003). Confidence benefits indicate the customers' desires for a stable relationship and confidence as its primary value (Patterson \& Smith, 2001).
According to Dagger and O'Brien (2010), there are several indicators of confidence benefits, which are:

1. Customers have confidence that the service will be provided correctly.

2. The customer's anxiety is reduced when using the services provided.

3. Customers know what to expect when using the service.

4. Customers get service at the highest level.

Social benefits are parts of emotional relationships that focus on introducing employees to the customers in a way that creates intimacy between employees and customers (Gwinner et al., 1998). Social benefits are beliefs received from a relationship with the hotel, at which the interaction between customers and employees is the main thing in the perception of customer quality (Reynolds \& Beatty, 1999). The social benefit concept is related to social interaction between employees and customers (Jones, Mothersbaugh, \& Beatty, 2000). Individual friendships and introductions add value to customer experiences that motivate customers to keep in touch with the hotel (Dagger et al., 2011).

There are several social benefit indicators (Dagger \& O'Brien, 2010):

1. Customers feel employees know them individually.

2. Customers feel familiar with hotel employees.

3. Customers have built a good relationship with the hotel.

4. Employees know the customers' names.

Special treatment benefits are related to faster service or individual service delivery to customers who have good relationships. There are two components of special treatment benefits that are economic and customization. Economic-based special treatment is a condition when customers receive faster service and benefit financially. While, customization-based benefit is a condition at which the hotel gives more attention to the customer through personal introduction (Gwinner et al., 1998). Through special treatment benefits, customers get discounts, can save time, and have additional services which are not provided to other customers in general (Ruiz-Molina, Gil-Saura, $\&$ Berenguer-Contri, 2009).

The indicators of special treatment benefits (Dagger \& O'Brien, 2010) are as follows:

1. Customers get discount or special price.

2. Customers get better prices than other customers.

3. Hotels provide services to customers that are not given to customers in general.

4. Customers are at the top of the queue list.

5. Customers get faster service than most customers. 


\section{Customer Commitment}

A firm or service provider tries to manage the establishment of a good business relationship that reflects mutual benefits for both the firm and its customer. The relationship benefits that customers receive from the firm should add value to their service experiences apart from what has been offered by the core product itself (Zineldin, 2006). Customers experiencing such relationship benefits will be satisfied when these benefits can fulfill and meet their needs and wants. Moreover, customers, who have a high level of satisfaction, will provide a positive boost that will create an emotional bond, namely customer commitment (Hennig-Thurau et al., 2002).

It is also suggested by Morgan and Hunt (1994) that firms will commit themselves to developing and maintaining long-term relationships with customers who also provide substantial benefits in return. This is similar with the results found by Hennig-Thurau et al. (2002) that relationship benefits are directly related to the level of commitment the customer may fell towards the service provider. Commitment is defined as an intention to develop and maintain long-term relationships between customers and the firm. It is a desire to maintain a valued relationship and also a psychological state that shapes an individual attitude in formulating a continual relationship with the firm (Morgan \& Hunt, 1994; Rauyruen \& Miller, 2007).

Finally, customer commitment represents the willingness of customers to remain with the firm and maintain such relationships in the long run with the firm. Both exchange parties, the customers and firm, encourage themselves to maintain the long-term and mutual benefits by remaining in the relationship (Morgan \& Hunt, 1994). Customer commitment reflects customers experience relationship closeness.

Some indicators of customer commitment (Dagger \& O'Brien, 2010) are as follows:

1. Customers fell the relationship with service provider is very important.

2. Both customers and service providers view the relationship as a long-term partnership.

\section{Customer Loyalty}

Customer loyalty is considered important because it has a long-term positive impact. Liang and Wang (2007) argue that long-term customers who are satisfied are more likely to buy additional services and spread good words of mouth than short-term customers. Loyal customers are defined as people who have favorable attitudes towards the hotel, recommend the hotel to other customers and want to make repurchase (Dimitriades, 2006). According to Uncles, Dowling, and Hammond (2003), loyalty is an ongoing trend to buy from a particular brand. So, it can be concluded that customer loyalty refers to favorable attitudes of customers to the hotel by promoting the hotel to others.

According to Griffin (2005), loyal customers are customers who have the following characteristics:

1. Customers repurchase products or services of the company regularly

2. Customers make purchases of all products or service lines offered by the company.

3. Customers recommend products or services to others using words of mouth.

4. Customers are not that interested in the products and services offered by competitors.

In addition to this, the indicators of customer loyalty (Dagger \& O'Brien, 2010) are as follows:

1. Customers spread positive things about the hotel to others.

2. Customers recommend the hotel to others who need it.

3. Customers encourage friends and relatives to establish cooperation with the hotel.

4. Customers consider the hotel as first choice.

5. Customers will continue business relationship with the hotel in the future.

6. Customers are willing to keep in touch with the hotel.

7. Customers are loyal to the hotel.

\section{The Relationship between Relationship Benefits and Customer Commitment}

Dagger and O'Brien (2010) conducted a study on the effect of relationship benefits and the quality of relationships on customer loyalty to customers who have used service industry and who have never used it. Three hundred and seventy-six questionnaires were distributed to customers from nine different service industries, like: health services, hairdressers, travel, photo printing, pest control, cinema, fast food, banks and airlines. The results of their study indicate that there is a positive and significant relationship between confidence benefits, social benefits and special treatment benefits to customer commitment.

Further study was also conducted by Dagger et al. (2011) on the influence of relationship benefits to customer loyalty with commitment as an intermediating variable. The research was conducted on customers from nine different service industries. Questionnaires were distributed to 591 respondents. The results show that there is a positive and significant influence between confidence benefits, social benefits and 
special treatment benefits to customer commitment. Confidence benefits have the greatest influence on commitment, and social benefits have a medium effect on customer commitment, while special treatment has little effect on customer commitment.

Based on the above researches, the hypotheses in this study are as follows:

$H_{1}$ : Confidence benefits have positive and significant impact on customer commitment.

$\mathrm{H}_{2}$ : Social benefits have positive and significant impact on customer commitment.

$H_{3}$ : Special treatment benefits have positive and significant impact on customer commitment.

\section{The Relationship between Customer Commitment and Customer Loyalty}

Hennig-Thurau et al. (2002) discuss the effect of relationship benefits, satisfaction and commitment to customer loyalty. The study was conducted in the United States with 336 total respondents, of which 173 respondents were women and 163 respondents were men with four age categories, 19-29 years, 3039 years, $40-49$ years, and more than 50 years old. From the results of this study, it is known that there is a positive and significant relationship between commitment and customer loyalty. A study by Dagger $e t$ al. (2011) also shows that there is a big positive influence of customer commitment on customer loyalty.

In addition, another research was done by Dimitriades (2006) about the influence of customer satisfaction and commitment on customer loyalty with the objects of 20 service providers consisting of four categories of financial services, retail, entertainment services, and transportation services in Greece with 200 respondents. The results show that there is a positive and significant relationship between commitment and customer loyalty. thesis is:

Based on the above researches, the next hypo-

$\mathrm{H}_{4}$ : Customer commitment has a positive and significant impact on customer loyalty.

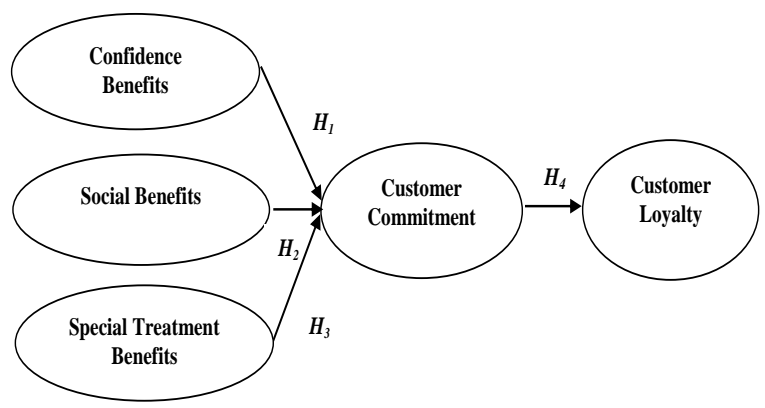

Figure 1. Research model

\section{Research Method}

This is a quantitative causal study with infinite population of those who have ever stayed in four-star hotels in Surabaya. A non-probability sampling is used with purposive sampling. The criteria of the sample are respondents aged over 17 years old and having stayed in four-star hotels in Surabaya at least twice a year in 2017. The minimum sample taken must be four to five times of total indicators (Malhotra, 2006). So, the minimum sample in this study must be at least 5 X 18 (90 respondents).

The questionnaires were distributed online and 296 respondents participating in this research. Unfortunately, only 150 questionnaires are valid as the rest do not meet the criteria, so the response rate is $50.6 \%$. Data are analyzed using Partial Least Square (PLS).

\section{Results and Discussions}

\section{Results}

The respondents in this research are mostly women (56\%), aged between 17-30 years old (78.67\%) with bachelor degree as much as $65.33 \%$. Most respondents have already stayed in Four Points by Sheraton (28\%) among any other four-star hotels in Surabaya. In addition, the respondents use to stay in the hotels with their family members $(62 \%)$ for leisure (32\%) with spending transaction between $\mathrm{Rp}$ $1,000,001.00$ to $\operatorname{Rp} 2,000,000.00$ (45.33\%). Their incomes per month are between Rp 2,000,001.00 to Rp 5,000,000.00 (37.33\%).

Likert scales are used with the following criteria: (1) strongly disagree, (2) disagree, (3) neutral, (4) agree, and (5) strongly agree. Using Partial Least Square (PLS), it is found that all indicators are valid as they have corrected item-total correlation bigger than 0.361 and all the variables have Cronbach Alpha bigger than 0.70 as per Table 1 . So, all indicators can be used for further analysis.

In addition, the results of convergent validity show that all indicators have outer loading which are bigger than 0.5 as per Table 2. Thus, these indicators can be used for further measurement.

Furthermore, from Table 3, it also shows that every variable has good composite reliability as their values are higher than 0.700 .

The outer model of the study can be seen as per Figure 2.

Path relationship among confidence benefits, social benefits, and special treatment benefits to customer commitment is obtained by $R$-square, which is equal to 0.5308 . It means that variation of respondent perception about customer commitment can be explained by confidence benefits, social benefits, and special treatment benefits as much as $53.08 \%$. While the rest of $46.92 \%$ is explained by other variables that are not analyzed in this study. 
Table 1

Validity and Reliability Tests

\begin{tabular}{lcc}
\hline \multicolumn{1}{c}{ Variables and Indicators } & Corrected Item-Total Correlation & Cronbach Alpha \\
\hline Confidence Benefits & 0.891 & 0.873 \\
Confidence in the service & 0.865 & 0.866 \\
Less anxiety & 0.781 & \\
Knowing what to expect & 0.756 & 0.842 \\
Good service & 0.865 & \\
Social Benefits & 0.864 \\
Individual recognition & 0.828 \\
Familiarity with employees & & 0.868 \\
Building a good relationship & 0.750 & \\
Knowing the customers' names & 0.888 & \\
Special Treatment Benefits & 0.895 & 0.850 \\
Special discount/ price & 0.863 \\
Special service & & \\
Priority & 0.935 & \\
Faster service & 0.931 & \\
Customer Commitment & & \\
Important relationship & 0.853 & 0.875 \\
Long term relationship & 0.862 & \\
Customer Loyalty & 0.860 & \\
Spreading positive things & 0.839 & \\
Making recommendation &
\end{tabular}

Table 2

Values of Outer Loading

\begin{tabular}{llc}
\hline \multicolumn{1}{c}{ Variables } & \multicolumn{1}{c}{ Indicators } & Values of Outer Loading \\
\hline Confidence Benefits & $X_{1.1}$ Confidence in the service & 0.895 \\
& $X_{1.2}$ Less anxiety & 0.863 \\
& $X_{1.3}$ Knowing what to expect & 0.866 \\
Social Benefits & $X_{1.4}$ Good service & 0.779 \\
& $X_{2.1}$ Individual recognition & 0.731 \\
& $X_{2.2}$ Familiarity with employees & 0.858 \\
& $X_{2.3}$ Building a good relationship & 0.870 \\
Special Treatment Benefits & $X_{2.4}$ Knowing the customers' names & 0.846 \\
& $X_{3.1}$ Special discount/ Price & 0.699 \\
& $X_{3.2}$ Special service & 0.892 \\
Customer Commitment & $X_{3.3}$ Priority & 0.913 \\
Customer Loyalty & $X_{3.4}$ Faster service & 0.881 \\
& $Y_{1}$ Important relationship & 0.929 \\
& $Y_{2}$ Long term relationship & 0.937 \\
& $Z_{1}$ Spreading positive things & 0.850 \\
& $Z_{2}$ Making recommendation & 0.859 \\
& $Z_{3}$ The company as the first choice & 0.860 \\
\hline
\end{tabular}

Table 3

Composite Reliability

\begin{tabular}{lc}
\hline \multicolumn{1}{c}{ Variables } & Composite Reliability \\
\hline Confidence benefits & 0.913 \\
Social benefits & 0.897 \\
Special treatment benefits & 0.912 \\
Customer Commitment & 0.930 \\
Customer Loyalty & 0.915 \\
\hline
\end{tabular}


The outer model of the study can be seen as per Figure 2 .

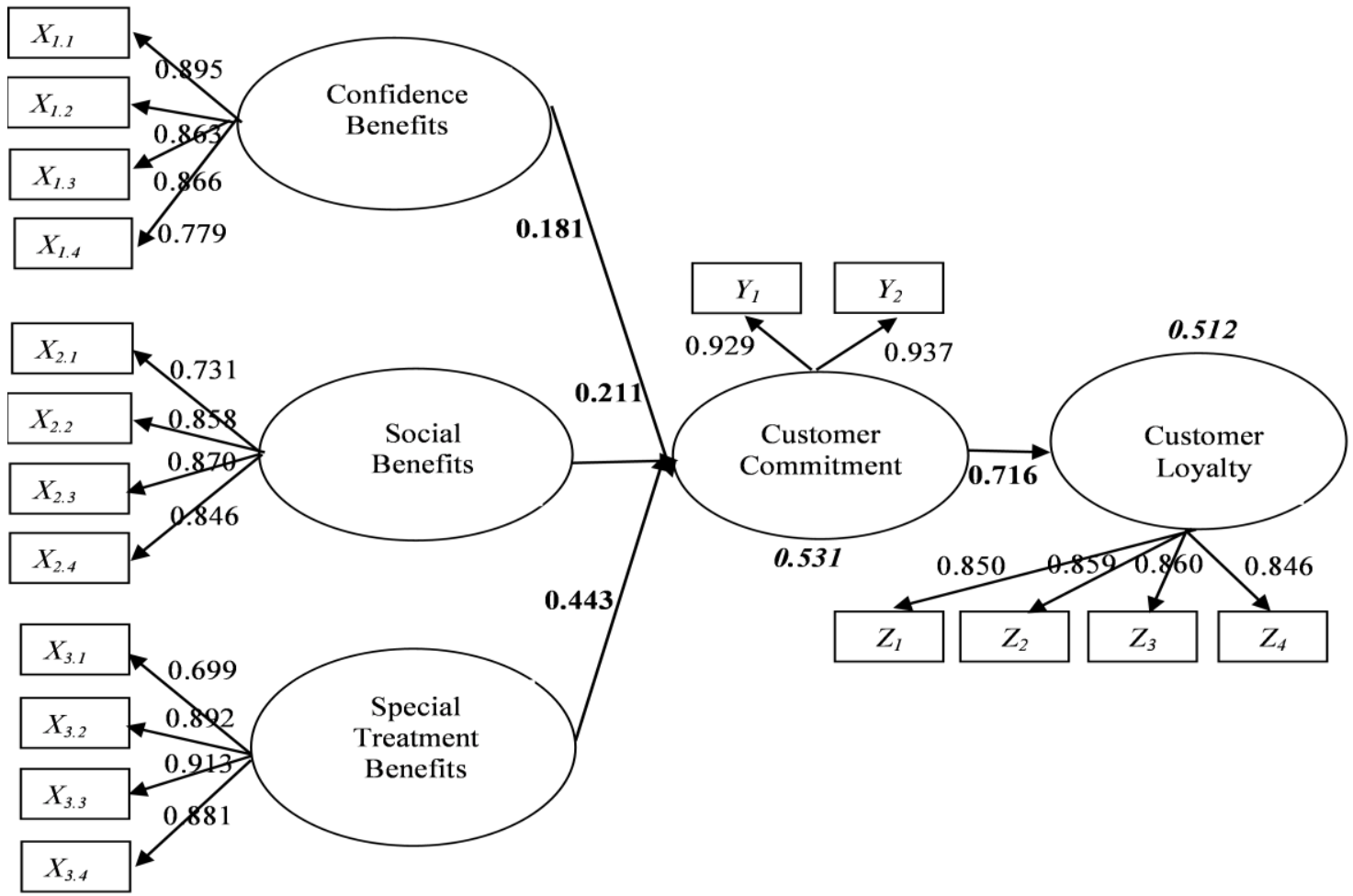

Figure 2. Outer model

\section{Figure 2. Outer model}

In addition, the relation between customer commitment to customer loyalty is obtained by $R$-square of 0.5121 which means that variation of respondent perception about loyalty can be explained by customer commitment as much as $51.21 \%$. Whereas the rest of $48.79 \%$ is explained by other variables that are not used in this study.

\section{Q-Square}

The value of $Q^{2}$ is obtained from $Q^{2}=1-\left(1-R_{I}^{2}\right)$ $\left(1-R_{2}^{2}\right)$ as follows:

$$
\begin{aligned}
Q^{2} & =1-\left(1-R_{1}^{2}\right)\left(1-R_{2}^{2}\right) \\
Q^{2} & =1-(1-0.5308)(1-0.5121) \\
& =1-(0.4692(0.4879) \\
& =1-0.2289 \\
& =0.771
\end{aligned}
$$

From the result, it can be said that PLS model can explain the influences of confidence benefits, social benefits, special treatment benefits with customer commitment to customer loyalty of fourstar hotels in Surabaya as much as $77.1 \%$. The rest of $22.9 \%$ is influenced by other variables that are

\begin{tabular}{|c|c|c|c|c|}
\hline Direct Influences & $\begin{array}{c}\text { Path } \\
\text { Coefficient }\end{array}$ & $\begin{array}{l}\text { Standard } \\
\text { Error }\end{array}$ & t-statistic & Remarks \\
\hline $\begin{array}{l}\text { Confidence benefits } \rightarrow \\
\text { Customer commitment }\end{array}$ & 0.181 & 0.076 & 2.375 & Significant \\
\hline $\begin{array}{l}\text { Social benefits } \rightarrow \\
\text { Customer commitment }\end{array}$ & 0.211 & 0.096 & 2.278 & Significant \\
\hline $\begin{array}{l}\text { Special treatment } \\
\text { benefits } \rightarrow \text { Customer } \\
\text { commitment }\end{array}$ & 0.443 & 0.100 & 4.672 & Significant \\
\hline $\begin{array}{l}\text { Customer commitment } \\
\rightarrow \text { Customer loyalty }\end{array}$ & 0.716 & 0.024 & 19.02 & Significant \\
\hline
\end{tabular}
not examined in this study.

\section{Inner Weight}

Table 4

\section{Direct Influences}

Based on Table 4, the influences of the variables are positive (Path coefficients are $0.181 ; 0.211 ; 0.443$; and 0.716 ) and significant (the values of all $t$-statistic >1.96). So all the four hypotheses are supported.

\section{Discussions}

Confidence benefits have positive (Path coefficient of 0.181) and significant influence on customer 
commitment. So, the first hypothesis is supported. Customers are very confident with hotel services as the hotel staffs make customer have less anxiety while interacting with them. Customers believe that the hotels deliver the best service they have. In addition, customers know what to expect while consuming four-star hotel services. The best service make

This is also in line with Hennig-Thurau et al. (2002) who state that confidence benefits enhance efficient relationship because they lower the costs required for a transaction to boost customer commitment. The finding of this study is consistent with previous researches by Dagger et al. (2011) and Dagger and O'Brien (2010) who stated that confidence benefits have a positive and significant impact on customer commitment. However, the findings of this study contradict with Hennig-Thurau et al. (2002) who stated that confidence benefits have no effect on customer commitment. This means that customers who have more confidence in the hotel will feel more secure and comfortable (Gwinner et al., 1998) and will affect the relationship with the hotel that will increase customer commitment to the hotel.

The second hypothesis mentioning social benefits have positive (Path coefficient of 0.211) and significant influence on customer commitment is also supported. Customers can have social interaction with hotel employees very well. The hotel employees have given personal recognition to every customer by providing his or her personal preferences while staying in the hotel. This intimacy has made customers feel very comfortable as the hotel employees build the social relationship by greeting customers with their names. Thus, it makes customers feel very welcome to stay in the hotels.

The result of this study is in accordance with Dagger et al. (2011) stating that social interaction and individual or personal recognition to customers add values to customers' experiences. Thus, it may result in a sustainable relationship that leads to customers' commitment to stay in the hotels in the future. Furthermore, Dagger and O'Brien (2010) study also prove that social benefits have positive and significant effect on customer commitment. When customers have close and intimate relationships with hotel employees, customers will have greater commitment to the hotels.

Moreover, special treatment benefits have positive (Path coefficient of 0.443) and significant influence on customer commitment. So, the third hypothesis is supported. Customers feel to be treated very specially as they can get special rates or discount. In addition, customers will get more priority and faster services compared to other customers, especially in the check in and check out processes. These special services can boost customer commitment to come back to the hotels again.

The result is in line with Dagger et al. (2011) who state that customers receiving a very special treatment from the hotels will feel compelled to repay what has been received so that it will foster customer commitment. Moreover, it is in accordance with studies conducted by Dagger and O'Brien (2010) stating that special treatments have positive and significant impact on customer commitment. This indicates that the higher level of privileges given by the hotel, the higher the level of customer commitment to stay again in the hotel will be.

The fourth hypothesis stating customer commitment has a positive and significant impact on customer loyalty is supported. Committed customers are willing to say positive things about the hotels. Even, customers do not hesitate to recommend the hotels to others and make the hotels as their first choice to stay in. Both customers and hotels trust each other to maintain sustainable and long-term relationships.

The results of this study support existing theories that committed customers are more likely to be loyal to hotels as customers feel that relationships are important (Moorman, Deshpandé, \& Zaltman, 1993). This is also in line with previous researches by Hennig-Thurau et al. (2002), Dagger et al. (2011) and Dimitriades (2006) saying that there is a positive and significant influence between customer commitment and customer loyalty. Committed customers tend to be loyal to the hotel.

\section{Conclusions and Implications}

From the findings, it can be concluded that confidence, social as well as special treatment benefits have influenced customer commitment positively and significantly. Thus, it means customer are committed to revisit the hotels when hotel employees are able to deliver good services as expected, create social bonds with customers that put them at ease as hotel employees also prioritize customers' need by giving special services and discounts. Furthermore, customer commitment has influenced positively and significantly on customer loyalty. So, the more committed the customers to the hotel, the more loyal the customers will be.

As special treatment benefits have the greatest impact on customer commitment, it is recommended that hotel management should be able to improve the service quality. This can be done by giving customers special discounts or special rates and prioritizing customers' needs especially when hotels are busy in high 
seasons. Hotels can also provide the personal necessity according to each customer's needs and wants. Service customization is a must for hotels to make customers committed and loyal. According Dagger and O'Brien (2010), the existence of customization is something that must be considered by service providers because customers do not like to be treated evenly. The higher degree of customization will make customer relationship with the service provider stronger and closer.

For further research, it would be good to distribute the questionnaires offline in order to get more accurate data. If online survey is deployed, the screening process should be more stringent by using Google-mail and the like. It is also recommended to have the other $22.09 \%$ factors that are not studied in this research.

\section{References}

Caceres, R. C., \& Paparoidamis, N. G. (2007). Service quality, relationship satisfaction, trust, commitment and business-to-business loyalty. European Journal of Marketing, 41(7/8), 836-867.

Cooil, B., Keiningham, T. L., Aksoy, L., \& Hsu, M. (2007). A longitudinal analysis of customer satisfaction and share of wallet: Investigating the moderating effect of customer characteristics. Journal of Marketing, 71(1), 67-83.

Dagger, T. S., David, M. E., \& Ng, S. (2011). Do relationship benefits and maintenance drive commitment and loyalty? Journal of Services Marketing, 25(4), 273-281.

Dagger, T. S., \& O'Brien, T. K. (2010). Does experience matter? Differences in relationship benefits, satisfaction, trust, commitment and loyalty for novice and experienced service users. European Journal of Marketing, 44(9/10), 1528-1552.

Dimitriades, Z. S. (2006). Customer satisfaction, loyalty and commitment in service organizations: Some evidence from Greece. Management Research News, 29(12), 782-800.

Griffin, J. (2005). Customer loyalty: Menumbuhkan dan mempertahankan kesetiaan pelanggan. Jakarta: Erlangga.

Gwinner, K. P., Gremler, D. D., \& Bitner, M. J. (1998). Relational benefits in services industries: The customer's perspective. Journal of the Academy of Marketing Science, 26(2), 101-114.

Hennig-Thurau, T., Gwinner, K. P., \& Gremler, D. D. (2002). Understanding relationship marketing outcomes: An integration of relational benefits and relationship quality. Journal of Service Research, 4(3), 230-247.
Industri perhotelan dan tren pariwisata di Indonesia. (2014, June). Industri perhotelan dan tren pariwisata di Indonesia. Retrieved September 3, 2016, from http://enciety.com/news-item/industri-perhotelan-dan-tren-pariwisata-di-indonesia-2/. Jones, M. A., Mothersbaugh, D. L., \& Beatty, S. E. (2000). Switching barriers and repurchase intentions in services. Journal of Retailing, 76(2), 259-274.

Kinard, B. R., \& Capella, M. L. (2006). Relationship marketing: The influence of consumer involvement on perceived service benefits. Journal of Service Marketing, 20(6), 359-368.

Liang, C. J., \& Wang, W. H. (2007). The behavioral sequence of information education services industry in Taiwan: Relationship bonding tactics, relationship quality and behavioral loyalty. Measuring Business Excellence, 11(2), 62-74.

Malhotra, N. K. (2006). Marketing research: An applied orientation. $5^{\text {th }}$ Edition. Upper Saddle River, NJ: Prentice Hall.

McColl-Kennedy, J. R., \& White, T. (1997). Service provider training programs at odds with customer requirements in five-star hotels. Journal of Services Marketing, 11(4), 249-264.

Moorman, C., Deshpandé, R., \& Zaltman, G. (1993). Factors affecting trust in market research relationships. Journal of Marketing, 57(1), 81-101.

Morgan, R. M., \& Hunt, S. D. (1994), The commitment-trust theory of relationship marketing. Journal of Marketing, 58(3), 20-38.

Patterson, P. G., \& Smith, T. (2001). Relationship benefits in service industries: A replication in a Southeast Asian context. Journal of Services Marketing, 15(6), 425-443.

Rauyruen, P., \& Miller, K. E. (2007). Relationship quality as a predictor of B2B customer loyalty. Journal of Business Research, 60(1), 21-31.

Reynolds, K., \& Beatty, S. (1999). Customer benefits and company consequences of customer-salesperson relationships in retailing. Journal of Retailing, 75(1), 11-32.

Ruiz-Molina, M. -E., Gil-Saura, I., \& BerenguerContrí, G. (2009), Relational benefits and loyalty in retailing: An inter-sector comparison. International Journal of Retail \& Distribution Management, 37(6), 493-509.

Triangga, B. A., \& Kurniawan, N. A. (2004). Pengaruh overall satisfaction, trust dan commitment terhadap future intentions pelanggan tetap hotel Surya Mojopahit Mojokerto. Unpublished Undergraduate Paper. Petra Christian University, Surabaya. 
Uncles, M. D., Dowling, G. R., \& Hammond, K. (2003). Customer loyalty and customer loyalty programs. Journal of Consumer Marketing, 20(4), 294-316.

Wong, M. O., Deans, K. R., \& Todd, S. (2003). Consumer relational benefits and switching in internet based electronic markets: A conceptual exploration. ANZMAC 2003 Conference Proceedings, 1767-1775.
Yen, H. J. R., \& Gwinner, K. P. (2003). Internet retail customer loyalty: The mediating role of relationnal benefits. International Journal of Service Industry Management, 14(5), 483-500.

Yonasari, N. (2019). Surabaya hotel market - Colliers International. Retrieved from https://www. colliers.com > apac > h2-2018-colliersquarterlysurabaya-hotel.

Zineldin, M. (2006). The royalty of loyalty: CRM, quality and retention. Journal of Consumer Marketing, 23(7), 430-437. 